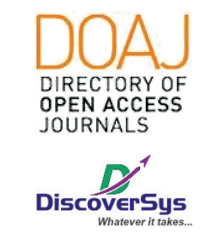

Published by DiscoverSys

\section{Perbedaan nilai Neutrophil Lymphocyte Ratio (NLR) terhadap pemeriksaan kultur darah dalam mendiagnosis sepsis pada pasien peritonitis di RSUP Sanglah, Bali, Indonesia}

\author{
I Putu Gede Sudiartha, ${ }^{1 *}$ I Ketut Wiargitha, ${ }^{2}$ Tjokorda Gde Bagus Mahadewa ${ }^{3}$
}

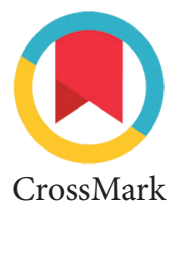

Background: Sepsis is a leading cause of death worldwide. A delayed or missed diagnosis of sepsis could increase its morbidity and mortality. The abdomen is the most common source of sepsis, which known as peritonitis-induced-sepsis. Peritonitis leads to an inflammatory and anti-inflammatory response. This study aims to elaborate on the role of Neutrophil Lymphocyte Ratio (NLR) as an easy, fast and inexpensive infection marker compared to blood culture, which known as the gold standard of sepsis in peritonitis patients.

Methods: This is a diagnostic study which combined secondary data taken at Sanglah Hospital Medical Record Department and new cases of generalized peritonitis patients with sepsis who came to Surgical Emergency Unit of Sanglah Hospital as the subjects. A total of 86 subjects, complete blood count analysis was done to calculate
NLR. Besides, 2-sided blood culture was tested to see whether the results were positive or negative. Data were analyzed using Stata/SE version 12.1

Results: We found that sensitivity of NLR compared to blood culture was $80 \%$ (Cl:63.1-91.6), with specificity of $88.2 \%$ (Cl:76.1-95.6), positive predictive value of $82.4 \%$ (Cl:65.5-93.2), negative predictive value of $86.5 \%$ (74.2-94.4), accuracy of $84.9 \%$ and likelihood ratio (LR) positive value of $6.8>1$. Our results showed that NLR has an enormous value in predicting the occurrence of sepsis in patients with generalized peritonitis.

Conclusion: NLR can be used as a screening tool for sepsis in generalized peritonitis patients because it has better sensitivity and accuracy, but it has to confirmed by blood culture as the gold standard.

Keywords: Sepsis, Generalized Peritonitis, Neutrophil Lymphocyte Ratio, Blood Culture

Cite This Article: Sudiartha, I.P.G., Wiargitha, I.K., Mahadewa, T.G.B. 2020. Perbedaan nilai Neutrophil Lymphocyte Ratio (NLR) terhadap pemeriksaan kultur darah dalam mendiagnosis sepsis pada pasien peritonitis di RSUP Sanglah, Bali, Indonesia. Intisari Sains Medis 11(1): 165-171. D0l: 10.15562/ism.v11i1.571

'Departemen IImu Bedah, Fakultas Kedokteran Universitas Udayana, RSUP Sanglah Denpasar, Indonesia ${ }^{2}$ Divisi Bedah Trauma dan Bedah Akut, Departemen IImu Bedah, Fakultas Kedokteran Universitas Udayana, RSUP Sanglah Denpasar, Indonesia

${ }^{3}$ Divisi Bedah Saraf, Departemen IImu Bedah, Fakultas Kedokteran Universitas Udayana, RSUP Sanglah Denpasar, Indonesia

\footnotetext{
*Korespondensi:

I Putu Gede Sudiartha; Departemen IImu Bedah, Fakultas Kedokteran Universitas Udayana, RSUP Sanglah, Denpasar, Indonesia;

dr.pgs1983@gmail.com
}

Diterima: 23-07-2019

Disetujui: 05-02-2020

Diterbitkan: 04-03-2020
Latar belakang: Sepsis merupakan penyebab kematian diseluruh dunia. Keterlambatan atau kesalahan dalam mendiagnosis dapat menyebabkan peningkatkan morbiditas dan mortalitas. Abdomen merupakan sumber penyebab paling sering terjadinya sepsis yang disebut dengan sepsis diinduksi peritonitis (peritonitis-induced sepsis). Penelitian ini bertujuan untuk menguji kemampuan Neutrophil Lymphocyte Ratio (NLR) sebagai marker infeksi yang mudah, cepat dan murah dibandingkan kultur darah yang merupakan standar baku dalam mendiagnosis sepsis pada pasien peritonitis.

Metode: Rancangan penelitan yang digunakan dalam penelitian ini adalah uji diagnostik dengan subjek penelitian merupakan gabungan antara data sekunder yang diambil di Instalasi Rekam Medis RSUP Sanglah serta identifikasi kasus baru yaitu pasien sepsis pada peritonitis generalisata yang datang ke IRD Bedah RSUP Sanglah sehingga jumlah total sampel 86 orang. Pasien kemudian diambil darah lengkap untuk nilai NLR dan kultur darah 2 sisi apakah hasilnya positif atau negatif. Data dianalisis menggunakan Stata/SE versi 12.1. Hasil: Dari penelitian ini didapatkan sensitifitas NLR dibandingkan dengan kultur darah adalah sebesar 80\% (Cl: 63,1-91,6) dengan spesifitas $88,2 \%$ (Cl: $76,1-95,6$ ), nilai prediktif positif 82,4\% (Cl: 65,593,2), nilai prediktif negatif $86,5 \%$ (Cl: $74,2-94,4)$ dan akurasi $84,9 \%$, serta nilai likelihood ratio (LR) positif didapatkan $6,8>1$. NLR mempunyai nilai yang besar dalam meprediksi terjadinya sepsis pada pasien peritonitis generalisata.

Simpulan: NLR dapat digunakan sebagai skrinning pasien sepsis pada peritonitis generalisata karena memiliki sensistifitas dan akurasi yang lebih baik tetapi tetap dikonfirmasi dengan kultur darah sebagai standar baku.

Kata kunci: Sepsis, Peritonitis Generalisata, Neutrophil Lymphocyte Ratio, Kultur Darah.

Cite Pasal Ini: Sudiartha, I.P.G., Wiargitha, I.K., Mahadewa, T.G.B. 2020. Perbedaan nilai Neutrophil Lymphocyte Ratio (NLR) terhadap pemeriksaan kultur darah dalam mendiagnosis sepsis pada pasien peritonitis di RSUP Sanglah, Bali, Indonesia. Intisari Sains Medis 11(1): 165-171. D0l: 10.15562/ism.v11i1.571 


\section{PENDAHULUAN}

Peritonitis merupakan inflamasi peritonium yang dapat terjadi karena kontaminasi mikroorganisme, bahan kimia, atau keduanya. ${ }^{1}$ Peritonitis generalisata dinyatakan sebagai infeksi yang terjadi akibat kegagalan pada peritonitis yang terlokalisir yang disebabkan karena kontaminasi yang cepat contohnya pada perforasi kolon, kontaminasi berulang serta pecahnya empiema yang masuk ke dalam kavum peritoneum. ${ }^{2}$ Survei yang dilakukan oleh World Society of Emergency Surgery menyatakan 88\% dari episode infeksi adalah infeksi nosokomial intra abdomen. Peritonitis generalisata didapatkan $43 \%$ dan $57 \%$ adalah peritonitis terlokalisir atau peritonitis abses dengan angka kematian $10 \%{ }^{3}$

Angka kematian akibat peritonitis di negara berkembang dilaporkan antara 13-43\%. ${ }^{4}$ Sebuah penelitian yang dilakukan oleh Riche dkk diperoleh dari 180 pasien dengan peritonitis generalisata ditemukan $41 \%$ mengalami syok sepsis dengan kematian 19\%. ${ }^{5}$ Selain itu, investigasi pada 68 institusi kesehatan di Eropa selama lebih dari 6 bulan mendapatkan 2.152 pasien dengan komplikasi infeksi abdomen dengan angka kematian 7,5\%. ${ }^{3}$

Setelah mendiagnosis dan memulai pengobatan, tidaklah mudah untuk memprediksikan prognosis dari sepsis. ${ }^{6}$ Berbagai marker, seperti sel darah putih, C-reaktif protein (CRP), procalsitonin (PCT), tumor necrosis factor- $\alpha$ (TNF- $\alpha$ ), dan beberapa sitokin (interleukin-6 dan interleukin-1) serta faktor koagulasi telah digunakan untuk mendiagnosis dan memprediksi prognosis dari sepsis. ${ }^{6}$ Pendekatan tradisional untuk diagnosis sepsis berdasarkan pada gejala dan temuan klinis yang didukung oleh data mikrobiologi. ${ }^{7}$ Upaya mengidentifikasi patogen penyebab sepsis dapat dilakukan dengan mengkultur penyebab sepsis, baik dari spesimen tubuh pasien atau dari lokasi sumber infeksi yang diduga dapat berkembang menjadi sepsis. ${ }^{8}$ Berbagai hasil penelitian terdahulu masih menyatakan bahwa kultur darah tetap sebagai baku emas dalam mendiagnosis sepsis. ${ }^{9}$

Respon fisiologis dari sistem imunitas tubuh ketika terjadi inflamasi sistemik adalah peningkatan jumlah neutrofil serta penurunan jumlah limfosit yang disebabkan oleh adanya regulasi apoptosis. ${ }^{10}$ Neutrofili dan limfositopenia terjadi dalam 4-8 jam setelah terjadinya cedera, kemudian menetap selama 2-7 hari, tergantung beratnya derajat cedera yang terjadi. Neutrofilia dan limfositopenia yang terjadi sebagai respon inflamasi akut tersebut menjadi dasar pengukuran rasio neutrofil dengan limfosit yang dikenal sebagai Neutrophyllymphocyte ratio (NLR) dan telah banyak dipergunakan juga pada kasus inflamasi kronis seperti pada keganasan. ${ }^{11}$ NLR merupakan parameter yang relatif lebih efektif dari segi biaya dan lebih mudah dihitung karena hanya membutuhkan hasil hitung darah lengkap. ${ }^{12}$ Rasio ini juga dinamakan "Neutrophil-Lymphocyte Stress Factor" tergantung pada efek fisiologis dari inflamasi sistemik serta tekanan pada neutrofil dan limfosit., ${ }^{5,13}$

Pemeriksaan marker untuk memprediksi kejadian sepsis tidak banyak bisa dilakukan oleh rumah sakit karena kendala pembiayaan. Berdasarkan pemaparan diatas, untuk menemukan marker yang lebih sederhana, murah dan cepat dalam memprediksi sepsis yang diinduksi oleh peritonitis, peneliti ingin mengetahui kemampuan NLR dibandingkan dengan kultur darah dalam mendiagnosis sepsis pada pasien dengan peritonitis generalisata.

\section{METODE}

Rancangan penelitian yang digunakan dalam penelitian ini adalah uji diagnostik dengan tujuan untuk mengetahui kemampuan NLR (Neutrophil Lymphocyte Ratio) dibandingkan dengan kultur darah dalam mendiagnosis kejadian sepsis pada pasien dengan peritonitis generalisata. Subjek penelitian didapat dari data sekunder yang diambil di Instalasi Rekam Medis RSUP Sanglah serta identifikasi kasus baru pasien dengan peritonitis yang datang ke Triage Bedah RSUP Sanglah dari bulan November 2018 - April 2019. Penelitian diawali dengan melakukan identifikasi pasien peritonitis generalisata, kemudian dilakukan penatalaksanaan sesuai dengan standar prosedur operasional serta dilakukan pemeriksaan laboratorium darah lengkap dan kultur darah. Selanjutnya pasien diikuti apakah terjadi sepsis atau tidak serta didapatkan hasil kultur.

Kriteria inklusi adalah semua penderita yang didiagnosis dengan peritonitis generalisata, pasien berumur lebih dari 18 tahun, pasien bersedia ikut serta dalam penelitian, dan menandatangani persetujuan tertulis atau informed consent. Berdasarkan perhitungan sampel penelitian, maka didapatkan 86 responden terlibat pada penelitian ini.

Kriteria eksklusi adalah pasien sedang menderita penyakit autoimun seperti SLE (systemic Lupus Erythematosus), sirosis hepatis, rheumatoid arthritis, insulin-dependent diabetes mellitus, Crohn's disease, dan primary vasculitis, pasien sedang menderita penyakit Imunodefisiensi yang dapat menyebabkan penurunan pada jumlah limfosit B, limfosit $\mathrm{T}$, dan makrofag seperti leukimia, limfoma, gagal ginjal akut, infeksi HIV, sarkodosis, splenektomi, dan infeksi virus Epstein-Barr, pasien yang meninggal sebelum diketahui sepsis dan diambil kultur darah. 
Data yang ada dilakukan analisis dengan Stata/ SE versi 12.1. Analisis deskriptif untuk memperoleh karakteristik subyek penelitian dan distribusi frekuensi berbagai variabel. Analisis bivariat untuk mengetahui kemampuan NLR (Neutrophil Lymphocyte Ratio) dalam memprediksi terjadinya sepsis pada pasien Peritonitis Generalisata menggunakan kurva ROC (Receiver Operating Characteristic). Penilaian kurva ROC berdasarkan kurva area under ROC disebutkan bila $\geq 70 \%$. Kemudian mencari titik potong terbaik dari NLR (neutrophil lymphocyte ratio) untuk memprediksi terjadinya sepsis dengan menentukan titik koordinat terjauh dari kurva ROC. Menentukan cut of poin dan AUC (Area Under Curve) dan kekuatan uji diagnostik (sensitivitas, spesifisitas, positive predictive value, negative predictive value, likelihood ratio), dan risiko relative dari nilai NLR dibandingkan dengan kultur darah. Uji bivariat untuk mengetahui hubungan dari masing-masing variabel bebas dengan variabel terikat dengan Chi Square. Selanjutnya dilihat nilai likelihood ratio (LR). Nilai $\mathrm{p}<0,05$ menunjukkan bahwa terdapat hubungan yang bermakna secara statistik. Data dianalisis dengan piranti lunak Stata/SE versi 12.1

\section{HASIL}

Titik potong yang dipergunakan dalam menentukan kriteria NLR adalah berdasarkan pada kurva ROC yang terdapat pada Gambar 1. Hasil analisis AUC pada ROC menunjukkan bahwa titil potong NLR sebesar 20,72 memiliki angka sensitivitas dan spesifisitas yang baik dalam mendiagnosis sepsis (Gambar 1). Berdasarkan hal tersebut, maka karakteristik subjek penelitian yang dijelaskan pada

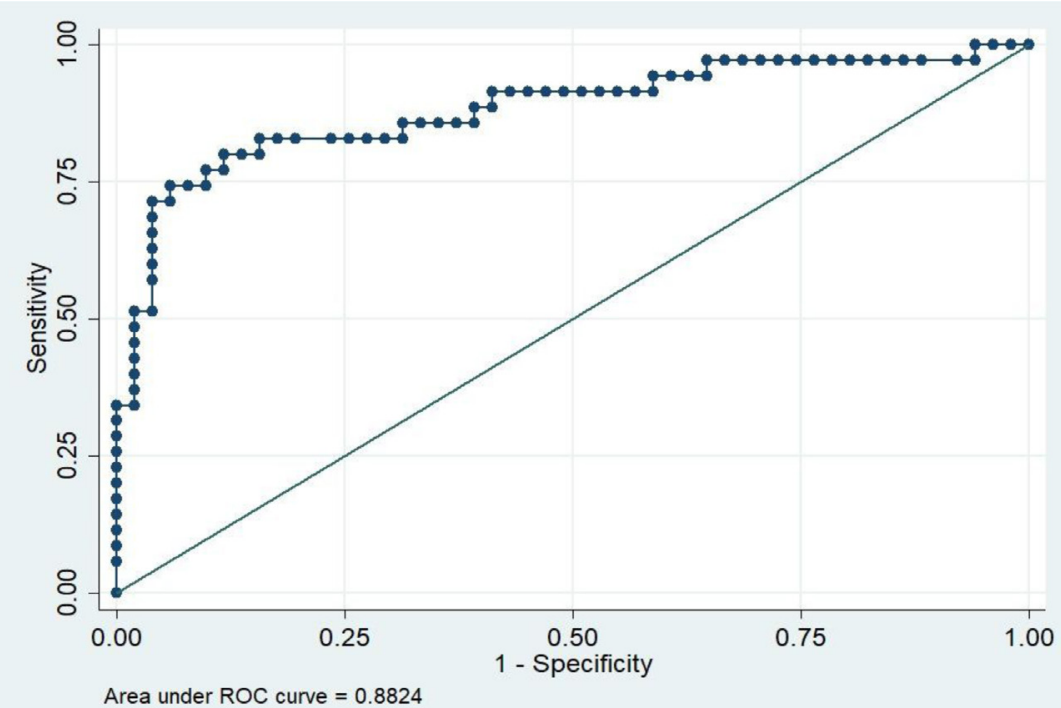

Gambar 1 Kurva ROC untuk menilai kemampuan dan titik potong terbaik NLR dalam mendiagnosis sepsis
Tabel 1 menunjukkan rerata usia pada NLR $<20,72$ adalah $51,36 \pm 17,15$ tahun sedangkan $\mathrm{NLR} \geq 20,72$ berusia 49,14 $\pm 13,96$ tahun. Sebagian besar responden berjenis kelamin laki-laki dengan NLR $<20,72$ sebanyak 34 responden $(65,38 \%)$ sedangkan NLR $\geq 20,72$ laki-laki sebanyak 21 responden $(61,76 \%)$ (Tabel 1). Karakteristik subjek penelitian berdasarkan penyebab peritonitis didapatkan lebih banyak karena nontrauma baik pada NLR $<20,72$ (92,31\%) dan NLR $\geq 20,72(88,24 \%)$. Lama hari perawatan lebih lama pada penderita dengan NLR $\geq 20,72$ dengan rerata $20.53 \pm 18,94$ hari. Pada outcome penelitian ini pada pasien peritonitis generalisata dengan sepsis didapatkan NLR $<20,72$ subjek penelitian yang hidup sebanyak 45 responden (86,54\%) dan NLR $\geq 20,72$ yang hidup sebanyak 23 responden $(67,65 \%)$ dengan $\mathrm{p}=0,035$ (Tabel 1 ).

Variabel yang dibandingkan dalam penelitian ini adalah Neutrophil lymphocyte ratio (NLR) dan kultur darah sebagai standar baku pada pasien sepsis dengan peritonitis generalisata. Tabel 2 menunjukkan nilai neutrofil didapatkan median 15,3 (2,0-53,83), limfosit didapatkan median $0,88(0,18-3,97)$, nilai Neutrophil lymphocyte ratio didapatkan median 17,1, dan hasil kultur darah positif sebanyak 35 pasien (40,7\%) (Tabel 2).

Hasil analisis kurva ROC (Gambar 1) pada penelitian ini menunjukkan sensitifitas neutrophil lymphocyte ratio (NLR) dengan nilai AUC $88,2 \%$. Secara statistik nilai AUC sebesar 88,2\% tergolong tinggi. Artinya apabila NLR digunakan untuk mendiagnosis terjadinya sepsis pada 86 pasien maka akan memberikan kesimpulan yang benar dalam menentukan ada tidaknya penyakit hanya 76 pasien. Secara klinis nilai AUC NLR cukup memuaskan karena lebih besar daripada nilai AUC minimal yang diharapkan peneliti ini yaitu sebesar 70\%. Cutt off point NLR terbaik terletak pada angka 20,72 (Gambar 1).

Uji validitas NLR dilakukan berdasarkan pada nilai titik potong atau cut of point kemudian dilakukan tabulasi silang (cross tabulation). Tabel 3 menunjukkan variabel NLR $\geq 20,72$ dengan kultur darah positif sebanyak 28 pasien dan kultur darah negatif sebanyak 6 pasien sedangkan NLR <20,72 didapatkan hasil kultur darah positif lebih sedikit yaitu 7 pasien dan kultur darah negatif 45 pasien. Hasil uji sensitifitas berdasarkan tabel $2 \times 2$ didapatkan $80 \%$, spesifitas $88,2 \%$, nilai prediktif positif $82,4 \%$, nilai prediktif negatif $86,5 \%$ dengan akurasi $84,9 \%$ (Tabel 3). Nilai Likehood Rasio (LR) positif didapatkan 6,8 dan nilai Likehood Rasio negatif didapatkan nilai 0,22 . Hal ini berarti nilai LR (+) didapatkan nilai 6,8 $>1$ mempunyai nilai yang besar dalam meprediksi terjadinya sepsis dan nilai LR (-) didapatkan nilai $0,22<1$ berarti NLR dalam memprediksi kejadian sepsis sangat jarang terjadi sepsis pada pasien yang tidak dengan peritonitis (Tabel 3). 
Tabel 1 Karakteristik dasar responden penelitian

\begin{tabular}{|c|c|c|c|}
\hline \multirow[b]{2}{*}{ Variabel } & \multicolumn{2}{|c|}{ NLR } & \multirow[b]{2}{*}{$\mathbf{P}$} \\
\hline & $<20,72(\mathrm{~N}=52)$ & $\geq 20,72(\mathrm{~N}=34)$ & \\
\hline Umur (tahun) (rerata \pm SB $)$ & $51,36 \pm 17,15$ & $49,14 \pm 13,96$ & 0,530 \\
\hline \multicolumn{4}{|l|}{ Jenis kelamin $(\mathbf{n}, \%)$} \\
\hline Laki-laki & $34(65,38 \%)$ & $21(61,76 \%)$ & 0,732 \\
\hline Perempuan & $18(34,62 \%)$ & $13(38,24 \%)$ & \\
\hline \multicolumn{4}{|l|}{ Penyebab peritonitis $(\mathbf{n}, \%)$} \\
\hline Trauma & $4(7,69 \%)$ & $4(11,76 \%)$ & 0,525 \\
\hline Non trauma & $48(92,31 \%)$ & $30(88,24 \%)$ & \\
\hline Lama perawatan $($ Hari $)($ rerata \pm SB $)$ & $14,12 \pm 10,47$ & $20.53 \pm 18,94$ & 0,162 \\
\hline \multicolumn{4}{|l|}{ Outcome (n,\%) } \\
\hline Hidup & $45(86,54 \%)$ & $23(67,65 \%)$ & 0,035 \\
\hline Meninggal & $7(13,46 \%)$ & $11(32,35 \%)$ & \\
\hline
\end{tabular}

Tabel 2 Gambaran Variabel Penelitian

\begin{tabular}{lcc}
\hline Variabel & $\begin{array}{c}\text { Median } \\
\text { (Minimum-Maksimum) }\end{array}$ & Persentase (\%) \\
\hline Neutrofil (1 x 103 ml) & $15,3(2,0-53,83)$ & \\
Limfosit (1 x 103 ml) & $0,88(0,18-3,97)$ & \\
Neutrophil Lymphocyte Ratio (NLR) & $17,1(2,01-63,3)$ & \\
Hasil Kultur (n,\%) & & $51(59,30 \%)$ \\
$\quad$ Negatif & & $35(40,70 \%)$ \\
$\quad$ Positif & & \\
\hline
\end{tabular}

Tabel 3 Uji Validitas NLR dengan Kultur Darah Terhadap Terjadinya Sepsis pada Pasien Peritonitis

\begin{tabular}{cccccccc}
\hline & \multicolumn{2}{c}{ Kultur Darah } & Sensitifitas \\
\cline { 2 - 7 } Variabel & Positif & Negatif & $\begin{array}{c}\text { Spesifitas } \\
\mathbf{9 5 \%} \text { IK }\end{array}$ & $\begin{array}{c}\text { NPP } \\
\mathbf{9 5 \%}\end{array}$ & $\begin{array}{c}\text { NPN } \\
\mathbf{9 5 \%} \text { IK }\end{array}$ & $\begin{array}{c}\text { Akurasi } \\
\mathbf{9 5 \%} \text { IK }\end{array}$ \\
\hline NLR & & & & & & & \\
$\geq 20,72$ & 28 & 6 & $80 \%$ & $88,2 \%$ & $82,4 \%$ & $86,5 \%$ & $84,9 \%$ \\
$<20,72$ & 7 & 45 & $(63,1-91,6)$ & $(76,1-95,6)$ & $(65,5-93,2)$ & $(74,2-94,4)$ & \\
\hline
\end{tabular}

NPN: nilai prediktif negatif, NPP: nilai prediktif positif, NLR: neutrophil lymphocyte ratio, IK: interval kepercayaan

\section{PEMBAHASAN}

Hasil penelitian menunjukkan rata-rata umur dalam penelitian didapatkan dengan umur 50,5 tahun dengan jenis kelamin terbanyak pada laki-laki. Penelitian sebelumnya oleh Angus dkk menyebutkan bahwa umur, jenis kelamin dan etnis tertentu berpengaruh terhadap insiden terjadinya sepsis berat dimana pada neonatus dan usia lanjut lebih tinggi dibandingkan dalam kelompok umur lainnya. ${ }^{14}$ Disamping itu, perempuan lebih tinggi dibandingkan laki-laki dan pada jenis kulit hitam lebih tinggi dibandingkan dengan kulit putih. ${ }^{14}$

Penyebab terbanyak peritonitis generalisata dalam penelitian ini adalah non trauma. Penelitian sebelumnya menyebutkan penyebab peritonitis juga tergantung pada jenis peritonitis. ${ }^{15}$ Peritonitis primer pada pasien dewasa disebabkan oleh penyakit sirosis hepatis dan asites, sedangkan pada anak-anak disebabkan oleh sindroma nefrotik dan Systemic Lupus Erythematosus (SLE).$^{15}$ Pasien asites yang disebabkan oleh penyebab lain, seperti gagal jantung, keganasan, penyakit autoimun, juga berisiko tinggi untuk berkembangnya peritonitis ini. Peritonitis primer juga dapat disebabkan oleh karena penggunaan kateter peritoneum, seperti pada kateter dialisis peritoneum. ${ }^{16}$

Peritonitis sekunder disebabkan oleh penyakit pada organ abdomen, trauma pada abdomen, dan operasi intra-abdominal sebelumnya. Penyakit 
pada organ abdomen, contohnya inflamasi usus (apendisitis dan divertikulitis), perforasi (gaster, neoplasma (karsinoma kolon), duodenum), dan vascular (ischemic colitis). Trauma pada abdomen dapat berupa trauma tajam, tumpul, atau iatrogenik. Peritonitis sekunder akibat komplikasi operasi, contohnya kebocoran anastomosis usus. ${ }^{17}$ Dalam sebuah studi, penyebab paling sering peritonitis sekunder, diantaranya perforasi ulkus peptikum (64\%), diikuti oleh perforasi usus kecil (24\%), dan perforasi apendisitis (12\%). Peritonitis tersier timbul akibat gagalnya terapi peritonitis atau karena imunitas pasien yang tidak adekuat. Gangguan sistem imun yang signifikan pada pasien dengan peritonitis teriser menyebabkan mikroorganisme dengan patogenik yang rendah untuk proliferasi dan menyebabkan penyakit ini. ${ }^{1,18,19}$ Penelitian ini hanya mendeskripsikan penyebab peritonitis generalisata karena trauma dan non trauma tanpa menelusuri secara mendalam kasus non trauma yang menjadi penyebab peritonitis tersebut.

Hasil penelitian didapatkan outcome dengan pasien hidup lebih banyak daripada yang meninggal dengan angka kematian 20,9\%. Peritonitis generalisata menurut Leppaniemi dkk didapatkan $43 \%$ dan $57 \%$ adalah peritonitis terlokalisir atau peritonitis abses dengan angka kematian $10 \%{ }^{3}$ Variabel NLR digambarkan dalam kurva ROC dan didapatkan sensitifitas NLR berdasarkan nilai AUC $88,2 \%$. Hal ini dapat dilihat pada titik- titik data yang menjauhi garis diagonal kurva dengan titik potong terbaik pada angka 20,72. NLR merupakan refleksi dari keseimbangan antara respon imunitas bawaan (neutrofil) dan imunitas adaptif (limfosit). Penjabaran tersebut menunjukkan bahwa pada inflamasi sistemik berat seperti sepsis berat serta syok septik, sistem imunitas tubuh berespon dengan terjadi peningkatan rasio neutrofil limfosit lebih besar bila dibandingkan dengan kondisi inflamasi sistemik yang ringan. ${ }^{11}$ Rasio neutrofil-limfosit dapat dihitung dengan mudah dari hasil pemeriksaan darah lengkap, serta merupakan marker yang mudah diperoleh yang dapat mengindikasikan status inflamasi pada tubuh. ${ }^{11}$

Standar baku emas dalam diagnosis sepsis masih didasarkan pada hasil kultur darah yang memerlukan waktu dalam pemeriksaannya. Standar diagnosis infeksi adalah isolasi dan identifikasi organisme dengan kultur darah, namun kekurangan metode diagnosis kultur adalah sensitifitas kurang optimal serta lamanya diagnosis. Sensitivitas kultur darah kurang sehingga hasil kultur negatif belum menyingkirkan diagnosis sepsis karena dari semua penderita sepsis hanya $20 \%$ - $40 \%$ yang menunjukkan hasil kultur positif. Kultur darah negatif biasanya didapatkan pada lebih dari $70 \%$ pasien sepsis, meskipun terdapat gejala klinis yang jelas akan adanya infeksi. ${ }^{20,21}$ Spesifisitas kultur darah terganggu karena potensi terjadinya kontaminasi. ${ }^{20,21} \mathrm{Hal}$ inilah yang menyulitkan penegakan diagnosis sepsis itu sendiri, meskipun SIRS, sepsis, sepsis berat dan syok sepsis biasanya berhubungan dengan infeksi bakteri tetapi tidak harus terdapat bakteremia. Bakteremia bersifat sepintas, dijumpai setelah jejas pada permukaan mukosa sehingga kultur darah tidak harus positif. Hal ini terjadi karena didalam sirkulasi darah kemungkinan terdapat endotoksin dan eksotoksin sedangkan bakterinya berada di dalam jaringan. ${ }^{22}$ Beberapa penelitian diatas menjadi alasan perlunya marker sepsis yang murah dan cepat seperti neutrophil lymphocyte ratio.

Dari penelitian diagnostik ini didapatkan sensitifitas NLR dibandingkan dengan kultur darah adalah sebesar $80 \%$ (IK:63,1-91,6) dengan spesifitas $88,2 \%$ (IK:76,1-95,6), nilai prediktif positif $82,4 \%$ (IK:65,5-93,2), nilai prediktif negatif $86,5 \%$ (IK:74,2-94,4) dan akurasi 84,9\%. Hasil penelitian ini berbeda dengan penelitian Kaushik dkk yang melibatkan 56 reponden menemukan pada kasus sepsis, NLR pada awal terjadinya sepsis didapatkan hasil secara signifikan lebih tinggi. ${ }^{23}$ Berdasarkan kurva ROC NLR pada hari pertama menunjukkan nilai AUC 0,911 dan $\mathrm{p}<0,001$ dengan sensitifitas $87,5 \%$ dan spesifitas $90 \%$. Nilai NLR hari kelima didapatkan nilai AUC 0,732 dan nilai signifikansi $<0,045$ dengan sensitifitas $73 \%$ dan spesifitas $71 \%$.

Penelitian Liu dkk tahun 2016 yang melibatkan 333 responden menemukan level NLR pada pasien dengan hasil kultur darah positif lebih tinggi secara bermakna dibandingkan dengan hasil kultur negatif. ${ }^{13}$ Nilai titik potong NLR pada penelitian ini didapatkan 23,8 dengan sensitifitas $81,3 \%$ dan spesifitas $53,6 \%$ dalam memprediksi kematian secara bermakna pada sepsis. Akan tetapi, penelitian Haloho dkk mendapatkan hasil yang berbeda dalam penelitiannya yang membandingkan NLR dengan procalcitonin. ${ }^{24}$ Penelitiannya melibatkan 35 reponden menemukan Rasio Neutrofil Limfosit dibanding dengan pemeriksaan procalcitonin pada infeksi bakteri pasien sepsis pada penelitian memiliki sensitivitas $57,89 \%$ dan spesifisitas $43,75 \%$ dengan cutt of point NLR pada nilai 10,195. ${ }^{24}$

Rosales dkk menyebutkan bahwa neutrofil merupakan leukosit pertama yang bermigrasi dari darah ke tempat yang mengalami cedera ataupun infeksi untuk membunuh patogen dan menyingkirkan debris seluler. ${ }^{25}$ Neutrofil bermigrasi ke lokasi inflamasi dan infeksi, yaitu tempatnya mengenali dan memfagositosis mikroorganisme yang menginvasi dengan tujuan untuk membunuhnya melalui mekanisme sitotoksik. Proses ini melibatkan mekanisme molekular yang mengkoordinasikan polarisasi sel, pengiriman reseptor, dan aktivasi 
integrin hingga tempat terjauh dari bermigrasinya neutrofil mengikuti kemoatraktan. ${ }^{25}$ Jika sudah tiba di tempat infeksi, neutrofil secara aktif memfagositosis mikroorganisme atau membentuk neutrophyl extracellular traps (NETs) untuk memerangkap dan membunuh pathogen. NADPH mereduksi kompleks oksidase pada membrane fagosomal untuk membentuk reactive oxygen species (ROS) dan pengiriman enzim proteolitik ke dalam fagosom untuk memulai penghancuran dan menyingkirkan patogen. ${ }^{25}$

Pada infeksi awal, nilai neutrofil cenderung mengalami penurunan, namun seiring berjalannya proses infeksi, nilai neutrofil cenderung mengalami peningkatan, baik dari segi jumlah dan distribusinya. Selama proses infeksi, agen kemotaksis akan menarik neutrofil ke area yang mengalami infeksi untuk menjalankan fungsinya dalam memfagosit dan membunuh mikroorganisme penyebab infeksi. ${ }^{26}$ Neutrofil merupakan regulator poten inflamasi melalui pelepasan faktor-faktor proinflamasi dan beberapa sitokin. Neutrofil memiliki dua peranan dalam mencetuskan dan mengontrol inflamasi. Mekanisme yang mengontrol hasil akhirnya belum digambarkan secara lengkap, namun fungsi yang berlawanan ini sangatlah berimbang. ${ }^{25}$

Rasio neutrofil-limfosit dapat dihitung dengan mudah dari hasil pemeriksaan darah lengkap, serta merupakan marker yang mudah diperoleh yang dapat mengindikasikan status inflamasi pada tubuh. Walaupun di beberapa literatur, mekanisme dari penggunaan rasio neutrofil limfosit sebagai marker inflamasi belum dapat dijelaskan secara terperinci, namun rasio neutrofil limfosit cukup sering digunakan sebagai marker inflamasi. ${ }^{16,17}$ Korelasi NLR dengan kategori sepsis ini juga ditemukan pada penelitian oleh Zahorec. ${ }^{27}$ Penelitian tersebut menyatakan bahwa adanya korelasi antara penurunan jumlah neutrofil dan peningkatan jumlah limfosit terhadap perbaikan kondisi klinis pasien SIRS dan sepsis. ${ }^{27}$ Penjabaran tersebut menunjukkan bahwa pada inflamasi sistemik berat seperti sepsis berat serta syok septik, sistem imunitas tubuh berespon dengan terjadi peningkatan rasio neutrofil limfosit lebih besar bila dibandingkan dengan kondisi inflamasi sistemik yang ringan. Akibat peningkatan jumlah neutrofil serta penurunan jumlah limfosit akan meningkatkan nilai rasio absolut antara neutrofil dan limfosit, jika dibandingkan dengan pasien tanpa reaksi inflamasi sistemik. Sejalan dengan peningkatan rasio neutrofil limfosit, maka risiko morbiditas dan mortalitas pasien yang ditandai dengan kerusakan dan kegagalan fungsi organ akan semakin meningkat. ${ }^{10}$

Neutrophil Lymphocyte Ratio merupakan refleksi dari keseimbangan antara respon imunitas bawaan (neutrofil) dan imunitas adaptif (limfosit).
Penjabaran tersebut menunjukkan bahwa pada inflamasi sistemik berat seperti sepsis berat serta syok septik, sistem imunitas tubuh berespon dengan terjadi peningkatan rasio neutrofil limfosit lebih besar bila dibandingkan dengan kondisi inflamasi sistemik yang ringan. Akibat peningkatan jumlah neutrofil serta penurunan jumlah limfosit akan meningkatkan nilai rasio absolut antara neutrofil dan limfosit, jika dibandingkan dengan pasien tanpa reaksi inflamasi sistemik. Sejalan dengan peningkatan rasio neutrofil limfosit, maka risiko morbiditas dan mortalitas pasien yang ditandai dengan kerusakan dan kegagalan fungsi organ akan semakin meningkat.

Penelitian Sonawane dkk pada neonatus kultur darah masih menjadi standar baku emas terhadap terjadinya sepsis bila dibandingkan dengan IT (Immature-to-Total neutrophil) rasio, micro ESR (Erythrocyte Sedimentation Rate), CRP, dan CBC (Complete Blood Count). ${ }^{28}$ Akan tetapi, peneliti belum menemukan penelitian yang membandingkan uji diagnosis yang melibatkan NLR dengan kultur darah pada pasien peritonitis generalisata terhadap terjadinya sepsis.

\section{SIMPULAN}

Hasil penelitian ini menunjukkan bahwa Neutrophil lymphocyte ratio (NLR) dapat digunakan sebagai skrinning pasien sepsis pada peritonitis generalisata karena memiliki sensistifitas dan akurasi yang lebih baik tetapi tetap dikonfirmasi dengan kultur darah sebagai standar baku.

\section{KONFLIK KEPENTINGAN}

Tidak terdapat konflik kepentingan dalam penulisan laporan penelitian ini.

\section{ETIKA PENELITIAN}

Persetujuan etik telah diperoleh oleh Komisi Etik, Fakultas Kedokteran, Universitas Udayana, RSUP Sanglah, Bali, Indonesia sebelum penelitian berjalan.

\section{PENDANAAN}

Penulis bertanggung jawab terhadap pendanaan penelitian ini tanpa melibatkan grant, pihak sponsor, atau sumber pendanaan lainnya.

\section{KONTRIBUSI PENULIS}

Seluruh penulis berkontribusi terhadap penelitian ini baik dari tahap penyusunan kerangka penelitian, pengumpulan data, analisis data penelitian, 
hingga interpretasi hasil laporan penelitian dalam bentuk publikasi.

\section{DAFTAR PUSTAKA}

1. Palmu A. Peritoniitti ja intra-abdominaaliset absessit [Peritonitis and intra-abdominal abscess]. Duodecim. 1979;95(23):1608-1616.

2. Mureșan MG, Balmoș IA, Badea I, Santini A. Abdominal Sepsis: An Update. J Crit Care Med (Targu Mures). 2018;4(4):120-125.

3. Leppäniemi A, Kimball EJ, De Laet I, Malbrain ML, Balogh ZJ, De Waele JJ. Management of abdominal sepsis--a paradigm shift?. Anaesthesiol Intensive Ther. 2015;47(4):400-408.

4. Khan PS, Dar LA, Hayat H. Predictors of mortality and morbidity in peritonitis in a developing country. Ulus Cerrahi Derg. 2013;29(3):124-130.

5. Riché F, Gayat E, Barthélémy R, Le Dorze M, Matéo J, Payen D. Reversal of neutrophil-to-lymphocyte count ratio in early versus late death from septic shock. Crit Care. 2015;19:439

6. Sandquist M, Wong HR. Biomarkers of sepsis and their potential value in diagnosis, prognosis and treatment. Expert Rev Clin Immunol. 2014;10(10):1349-1356.

7. Vincent JL, Beumier M. Diagnostic and prognostic markers in sepsis. Expert Rev Anti Infect Ther. 2013;11(3):265-275.

8. Sheldon IM. Detection of Pathogens in Blood for Diagnosis of Sepsis and Beyond. EBioMedicine. 2016;9:13-14.

9. Fan SL, Miller NS, Lee J, Remick DG. Diagnosing sepsis - The role of laboratory medicine. Clin Chim Acta. 2016;460:203-210.

10. Shen XF, Cao K, Jiang JP, Guan WX, Du JF. Neutrophil dysregulation during sepsis: an overview and update. J Cell Mol Med. 2017;21(9):1687-1697.

11. Prabawa IPY, Bhargah A, Liwang F, Tandio DA, Tandio AL, Lestari AAW, et al. Pretreatment Neutrophilto-Lymphocyte ratio (NLR) and Platelet-to-Lymphocyte Ratio (PLR) as a Predictive Value of Hematological Markers in Cervical Cancer. Asian Pac J Cancer Prev. 2019;20(3):863-868.

12. Savran Y, Megi T, Yilmaz B, Tokur ME, Ergan B, Yaka E, et al. Can neutrophil lymphocyte ratio predict disease severity and mortality in sepsis and septic shock Patients? Act Medica Mediterranea. 2018;34(3):877-882.

13. Liu X, Shen Y, Wang H, Ge Q, Fei A, Pan S. Prognostic Significance of Neutrophil-to-Lymphocyte Ratio in Patients with Sepsis: A Prospective Observational Study. Mediators Inflamm. 2016;2016:8191254.

14. Angus DC, van der Poll T. Severe sepsis and septic shock. N Engl J Med. 2013;369(9):840-851.
15. Sartelli M, Catena F, Di Saverio S, et al. Current concept of abdominal sepsis: WSES position paper. World J Emerg Surg. 2014;9(1):22.

16. Dilektasli E, Inaba K, Haltmeier T, et al. The prognostic value of neutrophil-to-lymphocyte ratio on mortality in critically ill trauma patients. J Trauma Acute Care Surg. 2016;81(5):882-888.

17. Núñez J, Núñez E, Bodí V, et al. Usefulness of the neutrophil to lymphocyte ratio in predicting long-term mortality in ST segment elevation myocardial infarction. Am J Cardiol. 2008;101(6):747-752.

18. Marshall JC. Intra-abdominal infections. Microbes Infect. 2004;6(11):1015-1025.

19. Lopez N, Kobayashi L, Coimbra R. A Comprehensive review of abdominal infections. World J Emerg Surg. 2011;6:7.

20. Riedel S, Melendez JH, An AT, Rosenbaum JE, Zenilman JM. Procalcitonin as a marker for the detection of bacteremia and sepsis in the emergency department. Am J Clin Pathol. 2011;135(2):182-189.

21. Schuetz P, Albrich W, Mueller B. Procalcitonin for diagnosis of infection and guide to antibiotic decisions: past, present and future. BMC Med. 2011;9:107.

22. Venet C, Zeni F, Viallon A, et al. Endotoxaemia in patients with severe sepsis or septic shock. Intensive Care Med. 2000;26(5):538-544.

23. Kaushik R, Gupta M, Sharma M, et al. Diagnostic and Prognostic Role of Neutrophil-to-Lymphocyte Ratio in Early and Late Phase of Sepsis. Indian J Crit Care Med. 2018;22(9):660-663.

24. Haloho AB, Irwanto FH, Theodorus, Gusnaintin R. Uji Diagnostik Rasio Neutrofil-Limfosit dibanding dengan Procalcitonin sebagai Biomarker Infeksi Bakteri Pasien Sepsis. Anesthesia \& Critical Care. 2017;35:121-31.

25. Rosales C, Demaurex N, Lowell CA, Uribe-Querol E. Neutrophils: Their Role in Innate and Adaptive Immunity. J Immunol Res. 2016;2016:1469780.

26. Liew PX, Kubes P. The Neutrophil's Role During Health and Disease. Physiol Rev. 2019;99(2):1223-1248.

27. Zahorec R. Ratio of neutrophil to lymphocyte counts-rapid and simple parameter of systemic inflammation and stress in critically ill. Bratisl Lek Listy. 2001;102(1):5-14.

28. Sonawane VB, Mehkarkar N, Gaikwad S, Kadam N. Comparison between sepsis markers and blood culture in diagnosis of neonatal sepsis: a prospective study. Int J Res Med Sci. 2017;5(4):1662-6.

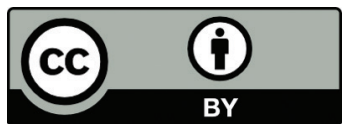

This work is licensed under a Creative Commons Attribution 